PAPER

\title{
Correlation of clinical findings, collision parameters, and psychological factors in the outcome of whiplash associated disorders
}

\author{
M Richter, R Ferrari, D Otte, H-W Kuensebeck, M Blauth, C Krettek
}

J Neurol Neurosurg Psychiatry 2004;75:758-764. doi: 10.1136/jnnp.2003.026963

See end of article for authors' affiliations ....................

Correspondence to: Dr Robert Ferrari, Room 2G2.06, W C MacKenzie Health Sciences Centre, University of Alberta Hospital, 8440-112 Street, Edmonton, Alberta, Canada T6G 2B7; rferrari@shaw.ca

Received 27 August 2003 In revised form 5 October 2003

Accepted 17 October 2003

\begin{abstract}
Objective: To determine prognostic factors for the duration and severity of acute symptoms in subjects with grade 1 or 2 whiplash injuries.

Methods: Collision victims presenting to a trauma centre with spinal pain or stiffness were assessed clinically (including a visual analogue scale (VAS)), radiologically, and psychologically (short form 36 (SF36), everyday life quality (EDLQ), pain control questionnaire (FSR)). Collision type and estimated $\Delta V$ (change in velocity of the occupant's vehicle) were also assessed. Assessment at six months involved VAS symptom rating, SF36, EDLQ, depression scale (CES-D), and impact of event scale (IES).

Results: 43 consecutive collision victims (22 male, 21 female; mean age 29 years (range 19 to 72 ) with grade 1 or 2 whiplash associated disorders were assessed. Mean $\Delta \mathrm{V}$, available for 36 of 43 collisions, was $13.9(5$ to 30$) \mathrm{km} / \mathrm{h}$. Thirty two $(74 \%)$ of the subjects were available for follow up at six months. The mean duration of symptoms was 28 (1 to 180) days in this group. No correlation was found between severity and duration of symptoms and the $\Delta \mathrm{V}$ of collision or other collision parameters. Patients with initial pain VAS $>5$ or with duration of symptoms more than 28 days had significant changes in SF36, EDLQ, CES-D, and IES scores at six months, and had initial scores that were predictive of these outcomes.

Conclusions: Psychological factors were found to be more relevant than collision severity in predicting the duration and severity of symptoms in collision victims with grade 1 or 2 whiplash associated disorders.
\end{abstract}

$\mathrm{R}$ ecent debate about chronic whiplash has focused on the significance of cultural factors and the role of psychosocial factors within a given culture. ${ }^{1-4}$ A recent study, for example, identified how the compensation system is an important factor in outcome. ${ }^{5}$ Not surprisingly, many countries have a high percentage of collision victims still reporting pain six weeks after the collision. ${ }^{4-6}$ Studies with fewer confounding variables have been conducted in Lithuania ${ }^{78}$ and Greece. ${ }^{9}{ }^{10}$ Germany, however, provides an even more useful opportunity to study the phenomenon of acute and chronic pain in whiplash victims. There is considerable attention to and litigation for acute injury in Germany, yet our research experience suggests that late whiplash syndrome is notably uncommon in this country. ${ }^{11} 12$ It may be that chronic pain after whiplash injury is as common in Germany as it is in many Western countries, but our clinical experience in primary care centres (rather than tertiary care referral centres, which may concentrate rare conditions) offers no evidence of this.

Our aim in this prospective study was to conduct a clinical, psychological, and technical assessment of whiplash victims and the collisions they suffered to determine the prognostic factors. All collision victims are covered by insurance in Germany, and this, together with the state health insurance, ensures that their medical expenses are paid and that they receive additional funding for any injuries that cause impairment. In addition, there is the possibility of litigation for compensation for impairment and pain and suffering.

\section{METHODS}

Subjects were recruited over a six month period from February 1999, after presentation to the Hannover trauma centre. They underwent evaluation at presentation and after six months. The area served by the hospital has approximately 300 whiplash injuries a year, about 150 coming to the
Hannover Medical School hospital emergency department. There was no funding for the study from an insurance company; funding was obtained through the state of Lower Saxony.

\section{Inclusion/exclusion criteria}

Whiplash type neck distortion was defined as a soft tissue injury of the neck following a vehicle collision. ${ }^{13}$ Subjects also met criteria for the Quebec Task Force grade 1 or 2 whiplash associated disorder. ${ }^{14}$ Fractures were excluded by $x$ ray, and ligamentous instabilities by lateral extension/flexion views. Subjects with multiple trauma beyond soft tissue injuries (that is, fractures), loss of consciousness, or with pre-existing neurological or psychiatric diseases were excluded. Those with back pain were not excluded.

\section{Initial assessment}

A registration sheet was filled out by an emergency physician. This including the following information:

- The collision. Time and location, position in vehicle, airbag deployment, restraint use, collision type, and vehicles involved.

- Medical history. Pre-existing diseases and current drug treatments.

- Symptoms. Presence, location, time of onset after collision, and severity (by a visual analogue scale (VAS), where 1 is, for example, "no pain/stiffness" and 10 is "maximum

\footnotetext{
Abbreviations: CES-D, Center for Epidemiologic Studies depression scale; EDLQ, everyday life quality; FSR, Fragebogen zur Schmerzregulation (pain control questionnaire); IES, impact of event scale; SF36; short form 36 item health questionnaire; VAS; visual analogue scale
} 
imaginable pain/stiffness"; time of onset and severity (VAS) of neck restriction; presence of vertigo, nausea, dysphagia, auditory and/or visual disturbance.

- Clinical findings. Tenderness or pain in the upper or lower neck region, occipital region, spinous processes, axial compression pain, and active/passive range of motion.

- Radiological findings.

- Neurological findings.

- Treatment prescribed.

- Psychological assessment. Short form 36 item health questionnaire (SF36, validated German version, standardised values), everyday life quality (EDLQ, validated German version), and pain control questionnaire (FSR, validated German version) using standardised instructions. ${ }^{15-17}$

- Collision mechanism. Determined by the accident research unit of the trauma department of Innsbruck University under supervision of the technical author (DO). Change in vehicle velocity $(\Delta \mathrm{V})$ at the time of the accident was estimated using a validated technique. ${ }^{18}$

\section{Follow up}

Only patients with a complete initial assessment (that is, including collision analysis) were considered for follow up. Six months after collision, subjects were mailed a cover letter, a packet of survey instruments, and a return envelope. Patients who failed to return the papers within seven days received a second mailing. If there was still no response, they were contacted by telephone. Those not completing the survey after phone contact, or who could not be reached within one month of the six months follow up date were considered lost to follow up.

The follow up survey contained the following:

- Medicolegal, functional, and treatment history: duration of work disability, existence of compensation claim and/or payment of damages, treatment type.

- Symptom assessment: duration and severity (VAS); severity (VAS) of limitations in daily activities.

- Psychological assessment: SF36, depression scale (CES-D, validated German version), impact of event scale (IES, validated German version), and EDLQ (validated German version). ${ }^{16-18}$

We did not include the FSR in the follow up, as our previous experience indicated that a large load of questions overwhelms the participants. We had other measures of pain at follow up, and we wished to include global measures of symptoms and health, so we did not require a follow up FSR.

\section{Data analysis}

We used $t$ tests, Pearson's test, Spearman rank test, $\chi^{2}$ tests, linear trend, or Kruskal-Wallis tests, as needed. Prognostic factors for the duration and severity of symptoms were determined in a decision tree analysis with $\mathrm{CART}^{\mathrm{TM}}$ (classification and regression trees). ${ }^{19}$

The psychometric categories for each instrument are as follows:

SF36: SF36PF, physical functioning; SF36RP, role physical; SF36BP, bodily pain; SF36GH, general health perception; SF36VT, vitality; SF36SF, social function; SF36RE, role emotional; SF36MH, mental health.

FSR: FSRSK1, capability; FSRSK2, pain intensity; FSRSK3, anxiety; FSRSK4, extent of depression; FSRSK5, avoidance; FSRSK6, resignation; FSRSK7, deflection.

IES: IESR1, intrusion; IESR2, avoidance; IESR3, arousal.
EDLQ: ALLTAG1, body; ALLTAG2, psyche; ALLTAG3, everyday life; ALLTAG4, social life; ALLTAG5, soulfulness; ALLTAG6, medical attendance.

\section{RESULTS}

\section{Demographic variables}

Of 73 consecutive collision victims, 30 were excluded (10 with loss of consciousness, with AIS grade 3 or 4 injuries; six with pre-existing significant neurological/psychiatric disease, nine with fractures, and five with $x$ ray evidence of ligamentous instability). Thus 43 collision victims were eligible for the study, and 32 of these were followed up at six months. Mean time of presentation for the 43 subjects was 97 minutes after the collision (range 30 minutes to 23 hours), and mean age was 28.9 years (range 19 to 72 ). Twenty two patients (51\%) were male and 21 (49\%) female. Twenty seven (63\%) were drivers, 10 (23\%) were front passengers, and six (14\%) were rear passengers. In seven cases $(16 \%)$ an airbag was present at the seating position of the injured person and was deployed in one case. Sixteen $(37 \%)$ of the collisions were rear end, $12(28 \%)$ were frontal, four $(9 \%)$ lateral, one (2\%) roll over, and $10(23 \%)$ were multiple collisions. The subjects recruited for follow up did not differ with those lost to follow up with respect to age, sex, collision type, incidence, onset, and severity and duration of symptoms or initial psychological scores (SF36, EDLQ, FSR).

\section{Initial clinical, radiological, and $\Delta \mathrm{V}$ findings}

Table 1 shows the prevalence, type, location, time of onset, and severity of the initial symptoms $(n=43)$.

Pain on pressure was found in the upper neck region in 13 $(30 \%)$ of cases, in the lower neck region in 19 (44\%), and over the cervical spinous processes and the occipital region in 11 (25\%). Neck pain was reported with axial compression of the spine in eight cases (19\%). Neurological deficits were detected in four cases (9\%), and were deemed by a neurologist to be the result of transitory hyposensitivity in the upper extremities in each case.

The mean passive range of motion of the cervical spine was as follows: extension $34.4^{\circ}$ (range $10^{\circ}$ to $60^{\circ}$ ); flexion $49.8^{\circ}$ (range $15^{\circ}$ to $80^{\circ}$ ); right lateral rotation $63.1^{\circ}$ (range $30^{\circ}$ to $\left.90^{\circ}\right)$; left lateral rotation $61.9^{\circ}$ ( range $30^{\circ}$ to $90^{\circ}$ ); right flexion $34.4^{\circ}$ (range $20^{\circ}$ to $60^{\circ}$ ); and left flexion $34.4^{\circ}$ (range $15^{\circ}$ to $\left.60^{\circ}\right)$.

The $x$ rays were normal in 31 cases $(72 \%)$. In the remainder, the abnormalities detected were as follows: straightening of the cervical lordosis in six $(14 \%)$, degenerative changes in three (7\%), and both straightening of the cervical lordosis and degenerative changes in three (7\%). No computed tomography or magnetic resonance imaging studies were done.

The mean $\Delta \mathrm{V}$ for the collisions involving 36 of the 43 subjects was $13.9 \mathrm{~km} / \mathrm{h}$ (range 5 to 30 ) (equivalent to 8.6 $\mathrm{mph}) . \Delta \mathrm{V}$ did not correlate with time of onset or the severity of the initial symptoms (Pearson's test, $\mathrm{p}>0.05$ ).

\section{Therapy}

Non-steroidal anti-inflammatory drugs were initially prescribed for 14 of the subjects (33\%). A hard cervical collar was used by eight patients with severe neck pain (18.6\%). Patients tend to use hard collars infrequently and for short periods because they are uncomfortable and very restrictive; however it is locally believed they help in the first few days if there is severe neck pain. We discouraged the use of a soft collar. Such collars are comfortable and so are often worn for long periods, which is known to be detrimental to outcome. ${ }^{12}$ All patients were treated as outpatients, with no other therapy reported. 
Table 1 Prevalence, type, location, time of onset (hours), and severity (visual analogue scale) of symptoms registered during the initial assessment of 43 collision victims

\begin{tabular}{|c|c|c|c|c|}
\hline Type & $\begin{array}{l}\text { Prevalence } \\
\text { (total } n=43 \text { ) }\end{array}$ & Location & $\begin{array}{l}\text { Time of onset in hours } \\
\text { (range) }\end{array}$ & Severity VAS (range) \\
\hline Pain & $81 \%(n=35)$ & $60 \%$ neck, $29 \%$ head, $4 \%$ shoulder, $6 \%$ others & $1.1(0$ to 12$)$ & $4.5(1$ to 8.5$)$ \\
\hline Stiffness & $46 \%(n=20)$ & $90 \%$ neck, $15 \%$ shoulder, $10 \%$ others & $3.0(0$ to 24$)$ & 4.8 (3.1 to 6.7$)$ \\
\hline Restriction of neck motion & $44 \%(n=19)$ & $100 \%$ neck, $10 \%$ shoulder & $1.5(0$ to 12$)$ & $4.0(0.5$ to 7$)$ \\
\hline Vertigo & $18 \%(n=8)$ & & $2.4(0$ to 12$)$ & $4.7(2$ to 9.2$)$ \\
\hline Nausea & $11 \%(n=5)$ & & $7.6(0$ to 24$)$ & 5.3 (3.9 to 9.2$)$ \\
\hline Dysphagia & $2.3 \%(n=1)$ & & 12 & 3.5 \\
\hline Visual disturbance & $4.6 \%(n=2)$ & & $6(0$ to 12$)$ & $4.8(4$ to 5.5$)$ \\
\hline Auditory disturbance & 0 & & & \\
\hline
\end{tabular}

\section{Initial psychological results}

Compared with reference values, ${ }^{15-17} 20$ the scores on initial psychological assessment (SF36, FSR, EDLQ) were normal in all subjects with mild or moderate symptom severity. For SF36, FSR, and EDLQ, subjects with more severe initial symptoms (VAS scores $\geqslant 4.5$ ) were more likely to have test scores outside the normal range than those who rated their initial symptoms as less severe (table 2).

\section{Six month follow up}

Thirty two patients returned all the instruments. This group did not differ from the whole group available for follow up

Table 2 Scores of the initial psychological assessment of 43 collision victims

\begin{tabular}{|c|c|c|c|c|c|c|c|}
\hline \multirow[b]{2}{*}{ Score } & \multirow[b]{2}{*}{ Category } & \multirow[b]{2}{*}{ Total $(n=43)$} & \multirow{2}{*}{$\begin{array}{l}\text { Sex } \\
M(n=22) \\
F(n=21)\end{array}$} & \multirow{2}{*}{$\begin{array}{l}\text { Age (years) } \\
<30(n=29) \\
\geqslant 30(n=14)\end{array}$} & \multirow{2}{*}{$\begin{array}{l}\text { Pain } \\
\begin{array}{l}V<5 \quad(n=20) \\
V \geqslant 5 \quad(n=15)\end{array}\end{array}$} & \multirow{2}{*}{$\begin{array}{l}\text { Stiffness } \\
\begin{array}{l}V<5 \quad(n=12) \\
V \geqslant 5 \quad(n=8)\end{array}\end{array}$} & \multirow{2}{*}{$\begin{array}{l}\text { Restriction* } \\
V<4(n=9) \\
V \geqslant 4(n=10)\end{array}$} \\
\hline & & & & & & & \\
\hline \multirow[t]{14}{*}{ FSR } & \multirow[t]{2}{*}{ FSRSK 1} & \multirow[t]{2}{*}{35.1} & 34.3 & 33.9 & 33.1 & 36.2 & 34.9 \\
\hline & & & 36.5 & 36.2 & 35.0 & 34.7 & 38.5 \\
\hline & \multirow[t]{2}{*}{ FSRSK2 } & \multirow[t]{2}{*}{28.2} & 28.2 & 26.6 & 30.4 & 29.4 & 28.4 \\
\hline & & & 28.1 & 28.6 & 26.8 & 26.4 & 30.3 \\
\hline & \multirow[t]{2}{*}{ FSRSK3 } & \multirow[t]{2}{*}{29.5} & 29.2 & 29.6 & 32.3 & 27.8 & 31.7 \\
\hline & & & 29.5 & 29.4 & 28.1 & 29.6 & 35.0 \\
\hline & \multirow[t]{2}{*}{ FSRSK4 } & \multirow[t]{2}{*}{23.5} & 23.7 & 25.1 & 26.4 & 24.2 & 24.1 \\
\hline & & & 23.1 & 23.0 & 22.6 & 22.9 & 26.0 \\
\hline & \multirow[t]{2}{*}{ FSRSK5 } & \multirow[t]{2}{*}{29.6} & 30.1 & 31.6 & 30.8 & 24.6 & 24.4 \\
\hline & & & 27.8 & 28.5 & 27.0 & 30.7 & 32.5 \\
\hline & \multirow[t]{2}{*}{ FSRSK6 } & \multirow[t]{2}{*}{28.3} & 27.5 & 28.6 & 29.6 & 29.2 & 26.8 \\
\hline & & & 28.8 & 27.2 & 26.0 & 27.5 & 30.8 \\
\hline & \multirow[t]{2}{*}{ FSRSK7 } & \multirow[t]{2}{*}{33.5} & 31.7 & 32.9 & 31.7 & 38.2 & 32.3 \\
\hline & & & 35.7 & 33.8 & 34.5 & 34.1 & 33.7 \\
\hline SF36 & SF36PF & 78.4 & 79.3 & 65.2 & 72.9 & 81.3 & 74.7 \\
\hline & & & 73.6 & 82.4 & 83.3 & 81.5 & 77.6 \\
\hline & SF36RP & 86.9 & 90.8 & 85.3 & 91.7 & 83.3 & 87.5 \\
\hline & & & 79.2 & 87.7 & 84.4 & 88.9 & 66.7 \\
\hline & SF36BP & 85.7 & 87.8 & 80.9 & 85.3 & 70.0 & 79.7 \\
\hline & & & 79.1 & 86.7 & 84.7 & 93.3 & 67.0 \\
\hline & SF36GH & 70.5 & 71.7 & 71.9 & 68.7 & 70.8 & 65.4 \\
\hline & & & 66.1 & 68.8 & 69.0 & 69.8 & 71.3 \\
\hline & SF36VT & 65.2 & 65.8 & 66.2 & 64.0 & 65.8 & 67.9 \\
\hline & & & 61.1 & 64.0 & 65.0 & 62.5 & 59.2 \\
\hline & SF36SF & 83.2 & 83.0 & 85.7 & 93.2 & 93.8 & 89.1 \\
\hline & & & 84.1 & 80.8 & 82.0 & 90.0 & 77.1 \\
\hline & SF36RE & 93.9 & 94.7 & 96.3 & 100.0 & 100.0 & 100.0 \\
\hline & & & 90.0 & 91.2 & 89.6 & 81.5 & 83.3 \\
\hline & SF36MH & 75.4 & 76.9 & 70.7 & 75.2 & 73.3 & 78.3 \\
\hline & & & 71.6 & 76.0 & 74.9 & 76.0 & 72.7 \\
\hline$E D L Q$ & ALLTAG1 & 39.2 & 39.0 & 38.3 & 46.2 & 41.0 & 41.6 \\
\hline & & & 39.6 & 40.1 & 39.3 & 38.9 & 41.0 \\
\hline & ALLTAG2 & 39.4 & 38.9 & 38.8 & 41.2 & 42.0 & 41.9 \\
\hline & & & 41.2 & 40.7 & 39.7 & 38.5 & 40.0 \\
\hline & ALLTAG3 & 39.7 & 39.0 & 38.5 & 42.3 & 42.4 & 41.9 \\
\hline & & & 40.5 & 40.9 & 40.2 & 39.7 & 41.8 \\
\hline & ALLTAG4 & 40.3 & 39.9 & 38.8 & 43.4 & 43.2 & 41.8 \\
\hline & & & 41.9 & 41.6 & 40.0 & 39.3 & 41.8 \\
\hline & ALLTAG5 & 13.3 & 13.3 & 12.9 & 14.1 & 14.2 & 14.1 \\
\hline & & & 13.5 & 13.5 & 13.3 & 13.0 & 13.8 \\
\hline & ALLTAG6 & 13.3 & 13.0 & 13.3 & 14.0 & 13.8 & 13.3 \\
\hline & & & 13.6 & 13.2 & 13.1 & 13.0 & 13.6 \\
\hline $\begin{array}{l}\text { For eac } \\
\text { score a } \\
\text { scores } \\
\text { *Restric } \\
\text { EDLQ, } \\
\text { analog }\end{array}$ & $\begin{array}{l}\text { a compari } \\
\text { re given in } \\
\text { red with eo } \\
\text { tion. } \\
\text { ife quality; }\end{array}$ & $\begin{array}{l}\text { f scores is made } \\
(t \text { test: } p<0.05 \text { ). } \\
\text { her (that is, mal } \\
\text { Fragebogen zur }\end{array}$ & $\begin{array}{l}\text { the groups } \\
\text { ex the text for } \\
\text { ex scores } v \\
\text { chmerzregulc }\end{array}$ & $\begin{array}{l}\text { ded according } \\
\text { finition of what } \\
\text { sex scores) by } \\
\text { ain control que }\end{array}$ & $\begin{array}{l}\text { sex, age, pain } \\
\text { measured by e } \\
\text { est, and with an } \\
\text { innaire); SF36 }\end{array}$ & $\begin{array}{l}\text { iffness, and rest } \\
\text { scale of the FSR } \\
\text { normative date } \\
\text { form } 36 \text { item h }\end{array}$ & $\begin{array}{l}\text { n of neck range } \\
6 \text {, and EDLQ. } \\
\text { a German pop } \\
\text { questionnaire; }\end{array}$ \\
\hline
\end{tabular}


( $n=36)$ in terms of age, sex, type of collision, prevalence, time of onset, psychological scores, or severity and duration of symptoms. Twenty one of the subjects (66\%) who completed disability instruments had no current disturbances in their daily life. One subject (3\%) felt impaired during work. Four subjects (13\%) felt an impairment during leisure, and six (19\%) during both work and leisure. All patients had returned to work at follow up. Twenty three patients (72\%) had no incapacity for work at all, three (9\%) had incapacity for one week, four (13\%) for two weeks, and one $(3 \%)$ each for four or 10 weeks. Two patients $(6 \%)$ were still under medical treatment at six months. Sixteen (50\%) obtained medical care only during the initial assessment in our emergency department on day 1 . Five (16\%) were medically treated for one week, one (3\%) for two weeks, five (16\%) for four weeks, two $(6 \%)$ for six weeks, and one $(3 \%)$ for 10 weeks. Nineteen subjects $(59 \%)$ stated that they had not claimed damages (entered litigation) or received any compensation; three $(9 \%)$ had not entered litigation but nevertheless had received compensation (without legal representation); and $10(31 \%)$ had entered litigation and had received payment. One subject $(8 \%)$ received the payments from his own collision insurance, and the remaining $12(92 \%)$ from the liability insurance of the other driver. Outcomes did not differ between litigants and non-litigants, but the samples were small in this regard. (The study by Cassidy et $\mathrm{al}^{5}$ is the most powerful and impeccable study to date to address this issue; it was not the purpose of our study to address it.)

Table 3 shows the prevalence, severity (VAS), and duration (days) of the symptoms as recalled at six months.

Table 4 shows the degree of limitations (VAS) in daily activities caused by spinal pain. The mean severity (VAS) of all symptoms was 3.8 (range 0.5 to 7.8 ), and the mean duration was 28 days (range 1 to 180 ). In six subjects (19\%) the symptoms persisted for one day or less, in $14(44 \%)$ for less than one week, in six (19\%) for one to four weeks, and in six $(19 \%)$ for more than four weeks. The average degree of limitation in daily life (VAS) at follow up at six months was 1.9 (range 0.3 to 5.6). As with the initial assessment, $\Delta \mathrm{V}$ did not correlate with the severity of the symptoms at six months, and no correlation was found between $\Delta \mathrm{V}$ and the duration of symptoms (Spearman's test, p>0.05). The psychological scores for IES and CES-D in patients with a longer duration of symptoms ( $>7$ days) or more severe symptoms (VAS >4.5) were outside the normal range, whereas for the remainder of the sample the scores were normal at follow up.

Predictive factors for more severe (VAS >4.5) and longer duration ( $>7$ days) of symptoms in the decision tree analysis with CART $^{\mathrm{TM}}$ (classification and regression trees) were limited to initial psychological measurements. There was no predictive value for age, sex, clinical or radiological findings, or collision parameters. The findings and scores of the initial psychological assessment allowed the subjects to be separated into two groups in terms of the initial severity of symptoms (group I, VAS $\leqslant 4.5$; group II, VAS $>4.5$ ) (see fig 1). The initial psychological assessment also allowed the subjects to be separated into two groups on the basis of the duration of their symptoms (group I, $\leqslant 7$ days; group II, $>7$ days).

\section{DISCUSSION}

Our study suggests that SF-36 test scores in the initial assessment in the categories "role physical," "bodily pain," "vitality," "social function," "role emotional," "avoidance," "pain intensity," and "everyday life" are prognostic factors predicting patients whose pain is of longer duration and greater severity. In general, greater initial anxiety is also a negative prognostic factor. At the same time, none of the anthropometric, clinical, radiological, or technical factors was predictive.

There are limitations to our study. Only 32 (74\%) of 43 eligible subjects entered and completed the study to follow up at six months. The initial symptoms, however, and their severity, is typical of whiplash patients in other studies. ${ }^{4-11}$ Further, non-responders did not differ from responders in terms of age, sex, type of collision, prevalence, time of onset, psychological scores, or severity and duration of symptoms. Thus it cannot be argued on the basis of the available data that the non-responders were any more likely to have a different outcome. Although there was a lower prevalence of degenerative changes on $x$ ray in our sample, numerous studies have shown that such changes are irrelevant to

Table 3 Prevalence, severity (visual analogue scale), and duration (days) of symptoms recalled by 32 restrained car occupants with acute whiplash syndrome at a six months follow up

\begin{tabular}{|c|c|c|c|c|c|}
\hline \multicolumn{2}{|c|}{ Severity (VAS) and duration of symptoms (days) } & \multirow{3}{*}{$\begin{array}{l}n \\
29\end{array}$} & \multirow{3}{*}{$\begin{array}{l}\% \\
90.6\end{array}$} & \multirow{3}{*}{$\begin{array}{l}\text { Mean } \\
4.3 \\
44.2\end{array}$} & \multirow{3}{*}{$\begin{array}{l}\text { Range } \\
1.1 \text { to } 7.5 \\
1 \text { to } 180\end{array}$} \\
\hline Neck pain & Severity & & & & \\
\hline & Duration & & & & \\
\hline \multirow[t]{2}{*}{ Head pain/headache } & Severity & 13 & 40.6 & 3.4 & 0.6 to 6.3 \\
\hline & Duration & & & 50.9 & 1 to 180 \\
\hline \multirow[t]{2}{*}{ Shoulder pain } & Severity & 2 & 6.3 & 3.4 & 2.5 to 4.3 \\
\hline & Duration & & & 100.5 & 21 to 180 \\
\hline \multirow[t]{2}{*}{ Other pain } & Severity & 2 & 6.3 & 2.8 & 2.3 to 3.2 \\
\hline & Duration & & & 100.5 & 21 to 180 \\
\hline \multirow[t]{2}{*}{ Neck stiffness } & Severity & 18 & 56.3 & 3.7 & 0.5 to 7.8 \\
\hline & Duration & & & 59.2 & 1 to 180 \\
\hline \multirow[t]{2}{*}{ Restriction of neck motion } & Severity & 19 & 59.4 & 3.6 & 1.1 to 7.6 \\
\hline & Duration & & & 34.4 & 1 to 180 \\
\hline \multirow[t]{2}{*}{ Vertigo } & Severity & 6 & 18.8 & 4.9 & 2.5 to 6.7 \\
\hline & Duration & & & 66.3 & 1 to 180 \\
\hline \multirow[t]{2}{*}{ Nausea } & Severity & 4 & 12.5 & 5.8 & 4 to 9.3 \\
\hline & Duration & & & 8.3 & 1 to 28 \\
\hline \multirow[t]{2}{*}{ Dysphagia } & Severity & 0 & 0 & & \\
\hline & Duration & & & & \\
\hline \multirow[t]{2}{*}{ Visual disturbance } & Severity & 1 & 3.1 & 3.5 & \\
\hline & Duration & & & 1.0 & \\
\hline \multirow[t]{2}{*}{ Auditory disturbance } & Severity & 1 & 3.1 & & \\
\hline & Duration & & & 1.3 & \\
\hline
\end{tabular}


Table 4 Severity (visual analogue scale) of symptoms or limitation in typical daily life situations in 32 restrained car occupants with acute whiplash syndrome at a six months follow up

\begin{tabular}{|c|c|c|c|c|}
\hline Symptom/limitation & $\mathbf{n}$ & $\%$ & $\begin{array}{l}\text { Mean } \\
\text { VAS }\end{array}$ & Range \\
\hline $\begin{array}{l}\text { How offen does neck pain disturb your sleep? } \\
\text { (VAS: } 0 \text {, never; } 10 \text {, always) }\end{array}$ & 6 & 18.8 & 1.6 & 1.1 to 2.4 \\
\hline $\begin{array}{l}\text { How often do you have neck pain at rest? } \\
\text { (VAS: } 0 \text {, never; } 10 \text {, always) }\end{array}$ & 5 & 15.6 & 1.9 & 1.2 to 3.2 \\
\hline $\begin{array}{l}\text { How severe is the rest pain then? } \\
\text { (VAS: } 0=\text { no pain, } 10=\text { maximum imaginable pain) }\end{array}$ & 5 & 15.6 & 2.2 & 0.4 to 4.3 \\
\hline $\begin{array}{l}\text { How often do you have pain during activity? } \\
\text { (VAS: } 0 \text {, never; } 10 \text {, always) }\end{array}$ & 3 & 9.38 & 2.5 & 0.9 to 5.5 \\
\hline $\begin{array}{l}\text { How severe is the pain during activity then? } \\
\text { (VAS: } 0 \text {, no pain; } 10 \text {, maximum imaginable pain) }\end{array}$ & 5 & 15.6 & 2.3 & 1.1 to 4.3 \\
\hline $\begin{array}{l}\text { How offen do you take medication for neck pain? } \\
\text { (VAS: } 0 \text {, never; } 10 \text {, always) }\end{array}$ & 4 & 12.5 & 2.3 & 2.1 to 2.4 \\
\hline $\begin{array}{l}\text { How well does the medication relieve the pain? } \\
\text { (VAS: } 0 \text {, very well, no more pain; } 10 \text {, no relief at all) }\end{array}$ & 4 & 18.8 & 1.8 & 0.7 to 4.5 \\
\hline $\begin{array}{l}\text { How long are you able to sit without symptoms in the neck? } \\
\text { (VAS: 0, for hours, without any limitation; } 10 \text {, not at all) }\end{array}$ & 10 & 31.3 & 1.8 & 0.3 to 3.2 \\
\hline $\begin{array}{l}\text { How do neck symptoms limit forward bending of the neck? } \\
\text { (VAS: } 0 \text {, no limitation at all; } 10 \text {, forward bending impossible) }\end{array}$ & 8 & 25 & 2.0 & 1.1 to 4.7 \\
\hline $\begin{array}{l}\text { How do neck symptoms limit your working ability? } \\
\text { (VAS: } 0 \text {, no limitation at all; 10, working impossible) }\end{array}$ & 4 & 12.5 & 2.8 & 1.1 to 5.6 \\
\hline $\begin{array}{l}\text { How do neck symptoms limit liffing of weights? } \\
\text { (VAS: } 0 \text {, no limitation at all; } 10 \text {, litting impossible) }\end{array}$ & 5 & 15.6 & 1.4 & 0.3 to 2.3 \\
\hline $\begin{array}{l}\text { How do neck symptoms limit housework? } \\
\text { (VAS: } 0 \text {, no limitation at all; } 10 \text {, housework impossible) }\end{array}$ & 7 & 21.9 & 1.9 & 1.0 to 3.2 \\
\hline $\begin{array}{l}\text { How long can you stand without neck symptoms? } \\
\text { (VAS: 0, for hours, without any limitation; 10, not at all) }\end{array}$ & 7 & 21.9 & 2.0 & 1.0 to 2.5 \\
\hline $\begin{array}{l}\text { How long can you walk without neck symptoms? } \\
\text { (VAS: 0, for hours, without any limitation; } 10 \text {, not at all) }\end{array}$ & 8 & 25 & 1.6 & 1.1 to 2.5 \\
\hline $\begin{array}{l}\text { How long can you run without neck symptoms? } \\
\text { (VAS: } 0 \text {, for hours, without any limitation; } 10 \text {, not at all) }\end{array}$ & 5 & 15.6 & 2.0 & 0.7 to 3.6 \\
\hline $\begin{array}{l}\text { How do neck symptoms limit daily life? } \\
\text { (VAS: 0, no limitation at all; } 10 \text {, daily life alone impossible) }\end{array}$ & 6 & 18.8 & 1.9 & 0.9 to 3.5 \\
\hline $\begin{array}{l}\text { How long can you travel without neck symptoms? } \\
\text { (VAS: } 0 \text {, for hours, without any limitation; 10, not at all) }\end{array}$ & 7 & 21.9 & 1.8 & 0.5 to 3.5 \\
\hline $\begin{array}{l}\text { How do neck symptoms limit sexual life? } \\
\text { (VAS: } 0 \text {, no limitation at all; } 10 \text {, impossible because of my neck) }\end{array}$ & 5 & 15.6 & 1.9 & 1.2 to 2.6 \\
\hline $\begin{array}{l}\text { How do neck symptoms limit carrying? } \\
\text { (VAS: } 0 \text {, no limitation at all; } 10 \text {, heary carrying impossible) }\end{array}$ & 4 & 12.5 & 1.8 & 0.5 to 4.5 \\
\hline
\end{tabular}

symptoms or outcome, a topic discussed in detail elsewhere. ${ }^{4}$ The possibility of missing a correlation between the extent or duration of complaints and age, sex, clinical or radiological findings, or technical parameters $(\Delta \mathrm{V}$, type of collision) is obviously greater than for studies with larger samples. Indeed, the high significance of the psychological responses as prognostic factors, despite the small sample size, suggests that the effect of psychological factors is substantial, and it is only factors with less influence that will be detected with larger sample sizes.

Collision victims in this region attend the emergency department as it is available at times when the general practitioner's office is closed. We excluded patients who have typically been excluded in other studies, and thus our study sample is representative of other studies of whiplash patients. Our study was of consecutive patients, and even if one assumes the worst about those lost to follow up (that is, that they all had chronic pain at six months), the theoretical (and very unlikely) $25 \%$ prevalence of chronic pain is still only half that found in similarly selected populations in North America. Alternatively, if one compares this study to one recently completed in Canada with the same inclusion criteria and the same rate of follow up, we see that the Canadian subjects have a prevalence of chronic pain that is five times higher than in our study. ${ }^{56}$ Although we used questionnaires, the same method used recently in Canada again shows a markedly different outcome, indicating either that there is a true difference across cultures when using 


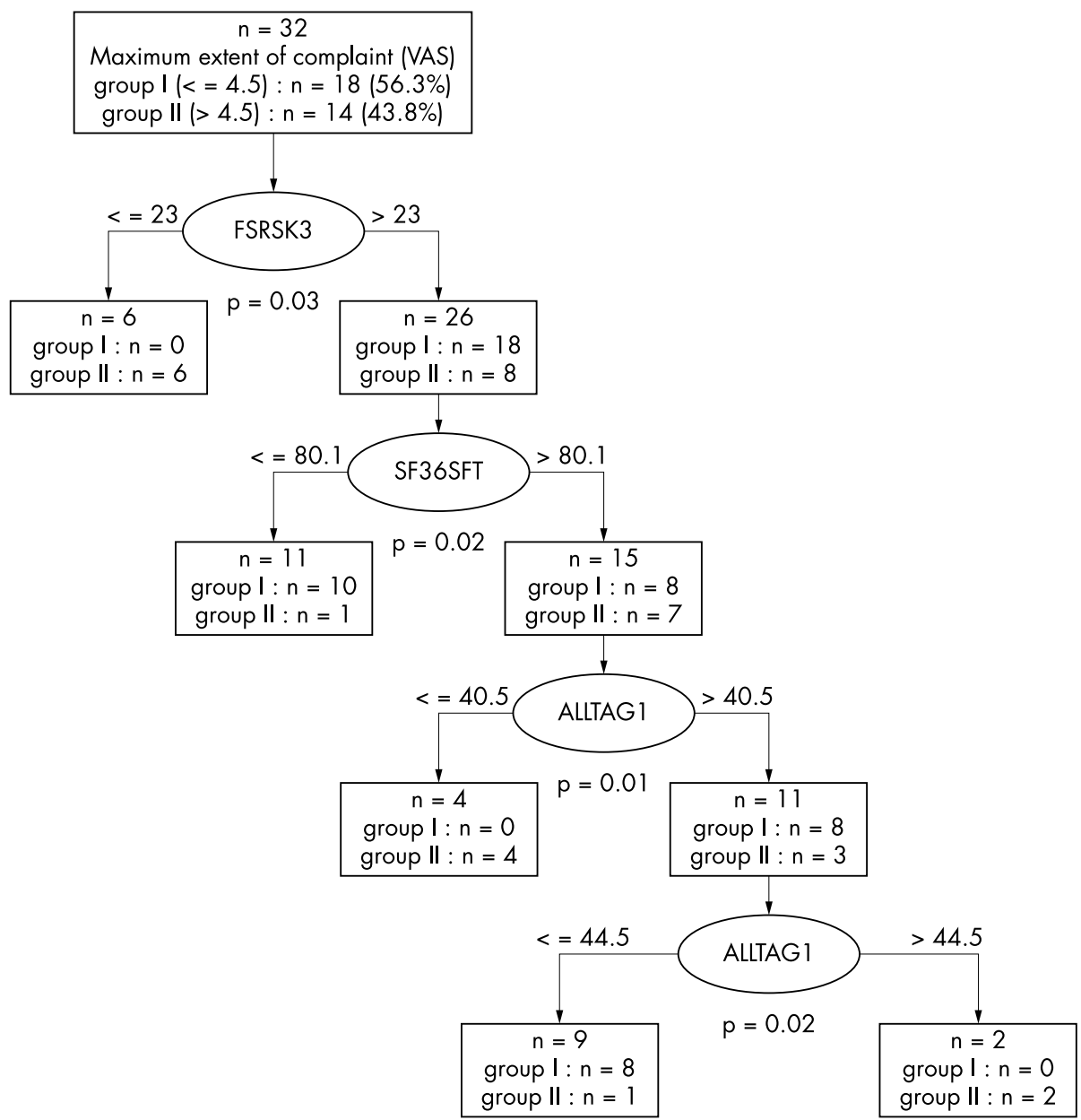

Figure 1 Decision tree analysis with $\mathrm{CART}^{\mathrm{TM}}$ (classification and regression trees) of 32 restrained car occupants with acute whiplash syndrome. The initial psychological assessment predicted assignment into group I (maximum severity of any symptom, visual analogue scale (VAS) $\leqslant 4.5 ; n=18$ ) and group II (VAS $>4.5 ; n=14$ ).

similar methodology, or that one must discount questionnaire follow up in both cases. We have no evidence that questionnaire follow up fails to detect chronicity. Our subjects all returned to work, which is in agreement with a previous study from Germany, ${ }^{11}$ thus suggesting that-at least for those attending trauma departments-our subjects are representative.

One should not assume that any subjects with chronic symptoms have necessarily suffered these as a result of the collision injury. We did not include a control population in our study, and this is critical for determining chronic effects of a collision, because musculoskeletal problems are very common in the general population of uninjured subjects. There are various independent risk factors for future neck pain besides a history of injury, and these risk factors will be present in whiplash patients. They include the number of children, poor health on self assessment, poor psychological status, and a past history of low back pain. ${ }^{21}{ }^{22}$ The importance of such additional risk factors was also shown in a landmark prospective Lithuanian study, where an age and sex matched healthy control group had the same prevalence of symptoms as a collision victim group at one year after the accident. ${ }^{8}$ It is possible that individuals of a certain psychological profile are more likely to have bodily symptoms in daily life, or are more likely to amplify such symptoms. They may also be more likely to seek a cause for their symptoms (and arbitrarily choose a collision six months previously). Yet minor symptoms are a part of daily life, and it can be seen from table 4 that the VAS scores indicated that the symptoms were on average minor in severity or frequency. The symptom prevalence in our subject population is consistent with comparative data from a German general population study. ${ }^{23}$

If biomechanical factors are relevant to chronic whiplash, then one is obligated to explain how Lithuanian, Greek, and German collision victims, for example, escape the influences of such factors, having an excellent outcome regardless of type of vehicle, amount of damage, restraint use, and presumably a variety of occupant postures and positions in the vehicle. ${ }^{7-11}$ In the current study, the extensive experience of the accident research unit allowed us to estimate $\Delta \mathrm{V}$ on the basis of an inspection of the vehicles alone. The distribution of the type of collision and $\Delta \mathrm{V}$ within the present study did not differ from an earlier retrospective study of 1176 collision victims. ${ }^{24}$ Seat belts are used by more than $80 \%$ of individuals in the geographical area investigated,,$^{24}{ }^{25}$ and all the subjects in our study were wearing them.

Despite increasing collision severity, the injury severity in vehicle occupants has decreased in the last 25 years. ${ }^{26-28}$ In contrast, the incidence of whiplash associated disorders has increased. ${ }^{29}$ These disorders also seem to follow low velocity collisions on many occasions. ${ }^{30}$ In the current study, $\Delta \mathrm{V}$ did not correlate with time of onset or the severity of the initial symptoms (Pearson test, $\mathrm{p}>0.05$ ). Initial symptoms and their duration cannot, therefore, be readily predicted by collision factors. 
We suggest that within a given culture, psychosocial factors are an important predictor of outcome. In particular, whiplash patients with more emotional disturbance initially have a worse prognosis. Put simply, culture rather than crash is the chief determinant of chronic pain after an acute whiplash injury.

\section{ACKNOWLEDGEMENTS}

We thank Mrs Birgitt Wiese (Institute for Biometry, Hannover Medical School) for her help and support in carrying out the extensive statistical analysis and for her unbiased evaluation.

\section{Authors' affiliations}

M Richter, C Krettek, Trauma Department, Hannover Medical School, Hannover, Germany

D Otte, Accident Research Unit, Hannover Medical School

H-W Kuensebeck, Department of Psychosomatics and Psychotherapy, Hannover Medical School

M Blauth, Trauma Department, University Innsbruck, Innsbruck, Austria R Ferrari, Department of Medicine, University of Alberta Hospital, Edmonton, Alberta, Canada

Competing interests: none declared

\section{REFERENCES}

1 Ferrari R, Russell AS. Whiplash: heading for a higher ground. Spine $1999 ; 24: 97-8$.

2 Ferrari R, Russell AS. Epidemiology of whiplash - an international dilemma. Ann Rheum Dis 1999:58:1-5.

3 Ferrari R, Schrader H. The late whiplash syndrome. A biopsychosocial approach. J Neurol Neurosurg Psychiatry 2001;71:722-6.

4 Ferrari R. The Whiplash Encyclopedia. The facts and myths of whiplash. Gaithersburg, Maryland: Aspen Publishers, 1999.

5 Cassidy JD, Carroll L, Cote P, et al. Effect of eliminating compensation for pain and suffering on the outcome of insurance claims for whiplash injury. N Engl J Med 2000;342:1179-86.

6 Brison RJ, Hartling L, Pickett W. A prospective study of acceleration-extension injuries following rear-end motor vehicle collisions. J Musculoskel Pain 2000;8:97-113.

7 Obelieniene D, Schrader H, Bovim G, et al. Pain after whiplash - a prospective controlled inception cohort study. J Neurol Neurosurg Psychiatry 1999;66:279-83

8 Schrader H, Obelieniene D, Bovim G, et al. Natural evolution of late whiplash syndrome outside the medicolegal context. Lancet 1996;347:1207-11.

9 Partheni M, Constantoyannis C, Ferrari R, et al. A prospective cohort study of the outcome of acute whiplash injury in Greece. Clin Exp Rheumatol $2000 ; 18: 67-70$.
10 Partheni M, Miliaris G, Constantayannis C, et al. Whiplash injury [letter]. J Rheumatol 1999;26:1206-7.

11 Bonk A, Ferrari R, Giebel GD, et al. A prospective randomized, controlled outcome study of two trials of therapy for whiplash injury. J Musculoskel Pain 2000;8:123-32.

12 Keidel M, Baume B, Ludecke C, et al. Prospective analysis of acute sequelae following whiplash injury. Vancouver, Canada: World Congress on Whiplash-Associated Disorders, 7-11 February 1999.

13 American Association for Automotive Medicine. Abbreviated injury scale revision 90. Morton Grove, Illinois: American Association for Automotive Medicine, 1995.

14 Spitzer WO, Skovron ML, Salmi LR, et al. Scientific monograph of the Quebec Task Force on whiplash associated disorders: redefining "whiplash" and its management. Spine 1995;20(suppl 8): 1-73S.

15 Bullinger M, Kirchberger I, von Steinbuechel N. Der Fragebogen Alltagleben - ein Verfahren zur Erfassung der gesundheitsbezogenen Lebensqualität. Z Med Psychol 1993;2:121-31.

16 Bullinger M, Kirchberger I. SF-36 Fragebogen zum Gesundheitszustand. Goettingen: Verlag für Psychologie, 1998.

17 Schermelleh-Engel K. Fragebogen zur Schmerzregulation (FSR). Frankfurt: Swets and Zeitlinger, 1995.

18 Otte D, Pohlemann T, Blauth M. HWS Distorsionen im geringen Unfallschwerebereich. Verkehrsunfall und Fahrzeugtechnik 1998;1:15-21.

19 Brieman L, Friedman J, Olshen R, et al. Classification and regression. Pacific Grove: Wadsworth, 1985

20 Jenkinson C, Coulter A, Wright L. Short form 36 (SF36) health survey questionnaire: normative data for adults of working age. BMJ 1993;306: 1437-40.

21 Croft P. Is life becoming more of a pain? BMJ 2000;320:1552-3.

22 Croft PR, Lewis M, Papageorgiou AC, et al. Risk factors for neck pain: a longitudinal study in the general population. Pain 2001;93:317-25.

23 Chrubasik S, Junck $\mathrm{H}$, Zappe $\mathrm{HA}$, et al. A survey on pain complaints and health care utilization in a German population sample. Eur J Anaesthesiol 1998; 15:397-408.

24 Richter M, Otte D, Pohlemann T, et al. Whiplash-type neck distortions in restrained car drivers - frequency, causes and long-term results. Eur Spine J 2000;9:109-17.

25 Walz E. Biomechanik und Verletzungsprävention im Strassenverkehr. Therapeutische Umschan 1997;54:238-41.

26 Loo GT, Siegel JH, Dischinger PC, et al. Airbag protection versus compartment intrusion effect determines the pattern of injuries in multiple trauma motor vehicle crashes. J Trauma 1996;41:935-51.

27 Richter M, Thermann H, Otte D, et al. Foot fractures in restrained car front occupants. A long-term study over 23 years. J Orthop Trauma 2001;15:287-93.

28 Wild BR, Kenwright J, Rastogi S. Effect of seat belts on injuries to front and rear seat passengers. BMJ (Clin Res Ed) 1985;290:1621-3.

29 Richter M, Otte D, Blauth M. Beschleunigungsverletzung der HWS beim gurtgeschützten PKW-Fahrer - Untersuchungen zu Unfallmechanismus und Verletzungsschwere. Orthopade 1999;28:414-23.

30 Richter M, Otte D, Blauth $M$, et al. Beschleunigungsverletzung der HWS beim gurtgeschützten PKW-Fahrer - Häufigkeit, Ursachen und Langzeitergebnisse. Unfallchirurg 2000;103:22-9. 